Las compañías se disuelven por: vencimiento del plazo de duración fijado en el contrato social, traslado del domicilio principal a país extranjero, auto de quiebra de la compañías, legalmente ejecutoriado, acuerdo de los socios, conclusión de las actividades para las cuales se formaron o por imposibilidad manifiesta de cumplir el fin social, pérdidas del $50 \%$ o más del capital social, reducción del número de socios o accionistas del mínimo legal establecido, no elevar el capital social a los mínimos establecidos en la Ley, inobservancia o violación de la Ley, de sus reglamentos o de los estatutos de la compañía, obstaculizar o dificultar la labor de control y vigilancia de la Superintendencia de Compañías, entre otras establecidas en el Art. 361 de la Ley de Compañías.

Disuelta la compañía se pondrá en liquidación, conservando su personalidad jurídica; pero, están prohibidos de hacer nuevas operaciones relativas al objeto social. Mientras no se inscriba el nombramiento de liquidador, continuarán encargados de la administración quienes hubieran venido desempeñando esa función, pero sus facultades quedan limitadas.

En la figura 3 en compañías disueltas y liquidadas del 2012 al 2013 existe un incremento del $130 \%$ con 371 compañías disueltas y liquidadas; y del 2013 al 2014 un crecimiento de 33\% con 214 compañías.

Figura 3.

Compañias Disueltas y Liquidadas

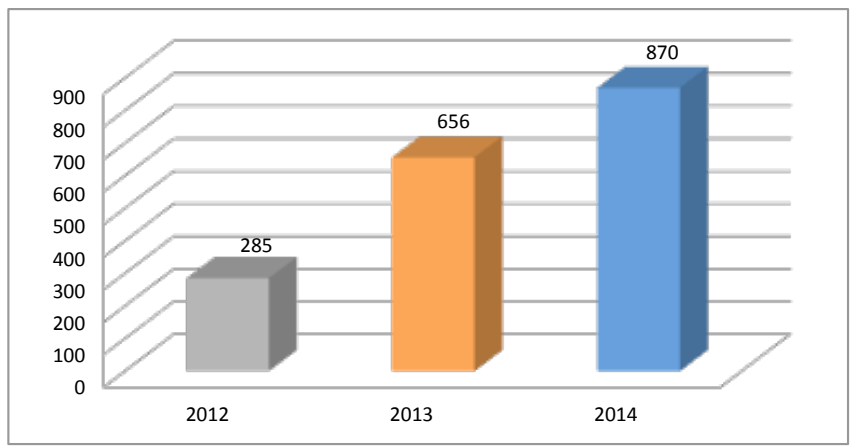

El Superintendente de Compañías, podrá ordenar la cancelación de la inscripción en el Registro Mercantil, de las compañías cuya disolución hubiere sido declarada, por lo menos con cinco años de anterioridad al 29 de junio de 1989, Art. 405

En lo posterior, emitida la resolución de disolución y si no hubiere terminado el trámite de disolución y liquidación en el lapso de un año, el Superintendente de Compañías podrá ordenar la cancelación de la inscripción en el Registro Mercantil correspondiente. El Superintendente de Compañías podrá cancelar el permiso de operación concedido a una compañía extranjera que tenga sucursal en el Ecuador, en los casos detallados en el Art. 406 de la Ley de Compañías.
En la figura 4 se determina que en el 2012 las compañías canceladas fueron 859 con un incremento del $2 \%$ con respecto al 2013, año en que las compañías canceladas fueron 876 y en relación al 2014 con un crecimiento de $12 \%$ con 984 compañías.

\section{Figura 4.}

Compañias Canceladas

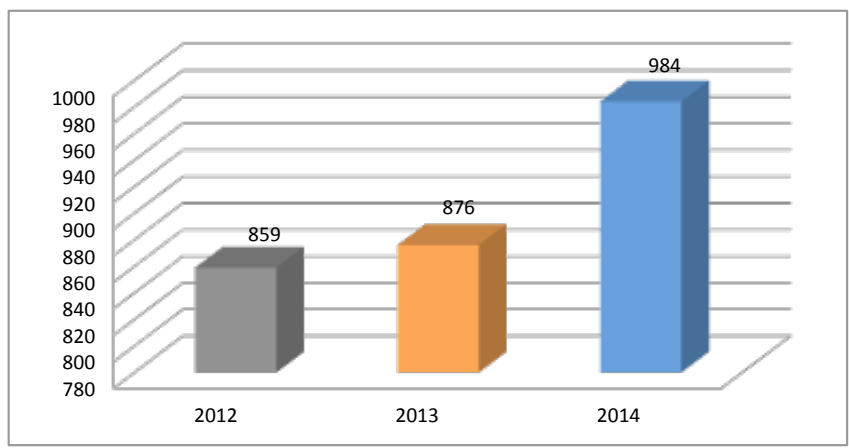

Fuente: Superintendecia de Compañias, Valores y Seguros

Elaboración: OBEST

Referencias:

Intendencia de Compañías, Valores y Seguros Ambato Ley de Compañías

Observatorio Económico y Social de Tungurahua (OBEST) Universidad Técnica de Ambato

Econ. Tatiana Vayas Carrillo. Lic. Sandra Garcés Mosquera.

Colaborador: Ing. Jorge Tamayo

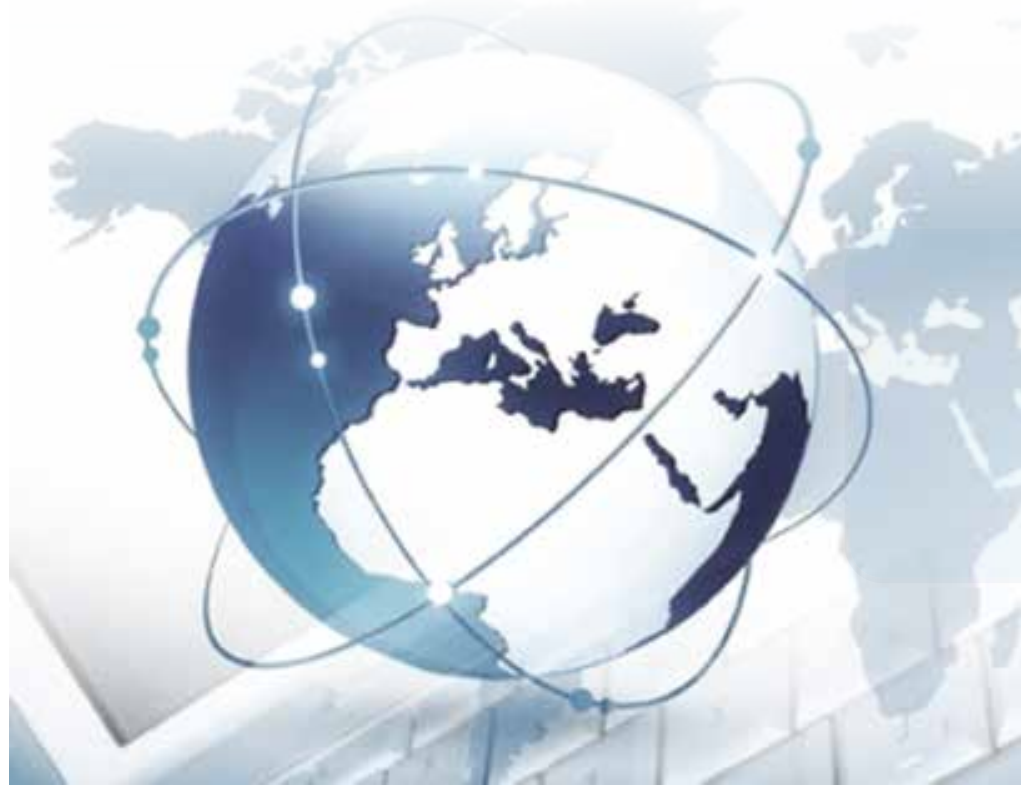

